\title{
EFFECT OF SUPERPHOSPHATE ON THE RETENTION OF PHOSPHORUS BY PEAT SOIL
}

\author{
ARMi KaILA \\ University of Helsinki, Department of Agricultural Chemistry
}

Received July 10,1959

The sorption of phosphate by soils is a phenomenon not as yet thoroughly known in spite of the intensive study devoted to it since the middle of the last century. As matters stand at present there are some generally accepted theories of the processes taking place in different kind of soils. According to the recent review by HEMwaLL (2) it can be concluded that phosphate retention in acid soils is primarily due to the formation of iron and aluminum compounds of the nature $\mathrm{M}\left(\mathrm{H}_{2} \mathrm{O}\right)_{3}(\mathrm{OH})_{2} \mathrm{H}_{2} \mathrm{PO}_{4}$. Regardless of whether the compounds are adsorbed on the surface of a soil mineral or precipitated, the compounds formed and the mechanism of reaction seem to be essentially the same. In calcareous and alkaline soils the phosphate retention is due to the formation of a series of insoluble calcium compounds which are solid solutions and quite heterogenous.

The phosphate retention capacity of soils is a relatively vague quantity. HiBBARD (3) states that "soils have no definite fixing power". The determination of the retention of phosphate by soils is quite empirical, and the results may depend on the concentration of phosphate added, the $\mathrm{pH}$, the time of reaction, the temperature, etc. even more than on the actual characteristics of the soil. Yet, given rigidly controlled experimental conditions, relative values are obtainable which at least to some degree, allow a comparison of the phosphate "retention capacity" of different soils.

The effect of various cations, anions, and organic compounds on the phosphate retention of soils has been studied especially under laboratory condition (e.g. 1, 6 9,12 etc.). It is possible, however, that also differences in the phosphorus conditions of the soil and in its treatment with phosphate fertilizers may affect the capacity of the soil to sorb phosphate. In the present paper this problem is treated on the basis of results obtained from the analyses of soil samples originating from a field trial on peat soil to which superphosphate has been continuously applied at different rates for 34 years. 


\section{Material and methods}

The soil samples were collected from a field trial at the Leteensuo Experiment Station. The soil is fairly well humified wood-Carex-peat, clayed at the outset of the experiment with $200 \mathrm{~m}^{3} /$ ha. No nitrogen fertilizers have been applied. Each year, all the plots received equal amounts of $40 \%$ potash fertilizers and the annual phosphate treatment was:

$$
\begin{aligned}
& \text { 1. } 0=\text { no superphosphate } \\
& \text { 2. } \mathrm{P}=100 \mathrm{~kg} / \mathrm{ha} \text { of superphosphate } \\
& \text { 3. } 2 \mathrm{P}=200 \\
& \text { 4. } 3 \mathrm{P}=300
\end{aligned}
$$

The ploughing layer of all the four replicate plots of each treatment was sampled. The samples were air-dried and ground.

A somewhat modified (4) method of TERÄsvUORI (11) was used for the characterization of the phosphorus condition in the peat samples. The phosphate exchange capacity was determined by PIPER's method (8).

The $\mathrm{pH}$-values were measured with a Beckman Zeromatic $\mathrm{pH}$-meter on 1: 2.5 mixtures of soil to water and soil to $1 \mathrm{~N} \mathrm{KCl}$.

Calcium in $1 \mathrm{~N}$ ammonium chloride extract and in the $\mathrm{HCl}$-extract of ash was determined with a flamephotometer.

Iron and aluminum were extracted by $0.1 \mathrm{HCl}, 2 \%$ citric acid, and TAMm's acid oxalate (10) in the ratio of 1 to 50 , the period of shaking being one hour. Iron was determined by Kunis's (5) mercurous nitrate method, and aluminum by the Aluminon method.

\section{Results}

The figures recommended by TERÄSVUORI (11) to characterize the phosphorus conditions of soil are reported in Table 1 for the peat samples of the various treatments. The mexchangeable $\mathrm{P}_{n}, \mathrm{x}_{0}$, was determined by extracting the samples with $0.1 \mathrm{~N} \mathrm{KOH}-\mathrm{K}_{2} \mathrm{CO}_{4}$ solution in a ratio of 1 to 100 for 18 hours. According to TERÄSVUORI, it represents the sesquioxide-bound inorganic phosphorus on which in acid soils the maintaining of the phosphorus concentration in soil solution largely depends. The effect of the different superphosphate treatments on this quantity is distinct. Only the lowest annual phosphate application has not been able to enhance the content of mexchangeable $P_{n}$ as compared to the untreated plots.

The data for the $\mathrm{P}$ concentration win soil solution", $\mathrm{y}_{0}$, were calculated according to the Freundlich adsorption isotherm to correspond to the equilibrium phosphate concentration of the samples when $x_{0}$ represents the adsorbed phosphorus. These values also reveal the effect of the added phosphate, although only the largest amount of superphosphate has markedly increased the phosphate concentration.

The indicator of the phosphate sorption capacity, denoted with $\alpha$ by TERÄSVUORI, is the coefficient of the Freundlich adsorption equation $\mathrm{x}=\alpha \mathrm{y} \frac{1}{\mathrm{n}}$, in which $\mathrm{x}$ is the amount of $\mathrm{P}$ sorbed and $\mathrm{y}$ the corresponding $\mathrm{P}$ concentration of the solution 
in equilibrium with the soil. It is of interest to note the effect of phosphate fertilization on this coefficient. In treatments $2 \mathrm{P}$ and $3 \mathrm{P}$ the figures are equal and distinctly higher than in treatment $\mathrm{P}$ and, particularly, in the samples from the untreated plots.

TERÄSVUORI introduced the ratio between the exchangeable $\mathrm{P}$ and the indicator of the sorption capacity, $\mathrm{x} / \boldsymbol{a}$, to indicate the relative $\mathrm{P}$ content of the soil, or the rate of saturation of the soil with phosphorus. These data are in accordance with the picture given by the values of $x_{0}$ and $y_{0}$ of the phosphorus conditions of the variously treated soils. It should be kept in mind that the coefficient $\alpha$ is not equal to the phosphate sorption capacity. It is only supposed to be correlated to this quantity the absolute determination of which is difficult or almost impossible. Consequently the figures for the rate of saturation in Table 1 only allow a mutual comparison.

Table 1. Phosphorus condition in the variously treated peat samples

\begin{tabular}{ccccc}
\hline Treatment & $\begin{array}{c}\text { Exchangeable } \\
\mathrm{P} \text { ppm } \\
\mathrm{x}_{0}\end{array}$ & $\begin{array}{c}\mathrm{P} \text { sin soil } \\
\text { solutions } \mathrm{mg} / \mathrm{l}\end{array}$ & $\begin{array}{c}\text { Indicator of } \mathrm{P} \\
\text { sorption ca- } \\
\text { pacity } \alpha\end{array}$ & $\begin{array}{c}\text { Relative } \mathrm{P} \\
\text { content of soil } \\
\mathrm{x}_{0} / \alpha\end{array}$ \\
\hline 0 & 48 & 0.04 & 244 & 0.19 \\
$\mathrm{P}$ & 74 & 0.06 & 308 & 0.24 \\
$2 \mathrm{P}$ & 129 & 0.10 & 393 & 0.33 \\
$3 \mathrm{P}$ & 269 & 0.43 & 406 & 0.66 \\
\hline L.S.D. 5\% & 33 & 0.05 & 36 & 0.04 \\
\hline
\end{tabular}

The coefficient $\boldsymbol{\alpha}$ largely depends on the ratio of soil to solution in the retention experiment, also the phosphate concentration of the solutions used exerts a marked effect on its absolute values. The data reported in Table 1 were obtained by $5 \mathrm{~g}$ of peat being allowed to remove $\mathrm{P}$ from $100 \mathrm{ml}$ of $\mathrm{KH}_{2} \mathrm{PO}_{4}$-solutions containing 15.5 and $155.0 \mathrm{mg} / 1$ of $\mathrm{P}$, respectively. When the ratio between soil and solution is changed to $1: 10$, and different concentrations of phosphate in solutions are used, the following values for $\alpha$ may be found:

Treatment

$\mathrm{P}$ in the original solutions

3.1 and $31.0 \mathrm{mg} / \mathrm{l} \quad 15.5$ and $155.0 \mathrm{mg} / \mathrm{l} \quad 31.0$ and $310.0 \mathrm{mg} / \mathrm{l}$

$\begin{array}{rrrr}0 & 82 & 137 & 172 \\ \mathrm{P} & 86 & 169 & 222 \\ 2 \mathrm{P} & 179 & 212 & 270 \\ 3 \mathrm{P} & 259 & 262 & 291\end{array}$

In every case, however, there is the same order between the values for $\alpha$ : the higher the annual treatment with superphosphate, the higher the indicator of the phosphate sorption capacity.

The phosphate exchange capacity of the samples was determined by the method introduced by PIPER (8) in which the soil is first saturated with phosphate at pH 4.0, 
after which the sorbed phosphate is exchanged with sodium hydroxide. The figures obtained by this method were fairly high:

$\begin{array}{ccccc}\text { Treatment } & 0 & \mathrm{P} & 2 \mathrm{P} & 3 \mathrm{P} \\ \text { Exchange capacity, P ppm } & 13930 & 13750 & 14560 & 14950\end{array}$

The significant difference at 5 per cent level is $470 \mathrm{ppm}$ which means that there are no differences between treatments 0 and $\mathrm{P}$ on the one hand, and between treatments $2 \mathrm{P}$ and $3 \mathrm{P}$ on the other hand. However, the phosphate sorption capacity of the two latter treatments is significantly higher than that of the lower treatments.

The removal of the phosphate from solution by the various peat samples was further studied by a series of experiments in which the samples were heated for two hours on two consecutive days over a boiling water bath. The ratios of soil to solution were 1 to 10 and 1 to 20 . The concentrations of the $\mathrm{KH}_{2} \mathrm{PO}_{4}$-solutions varied from 0 to $1550 \mathrm{mg} / 1$ of $\mathrm{P}$. These results are recorded in Table 2 as the phosphate concentrations in the filtrate at the end of the treatment.

Table 2. Phosphorus, $\mathrm{mg} / \mathrm{l}$, in solution in equilibrium with the peat samples

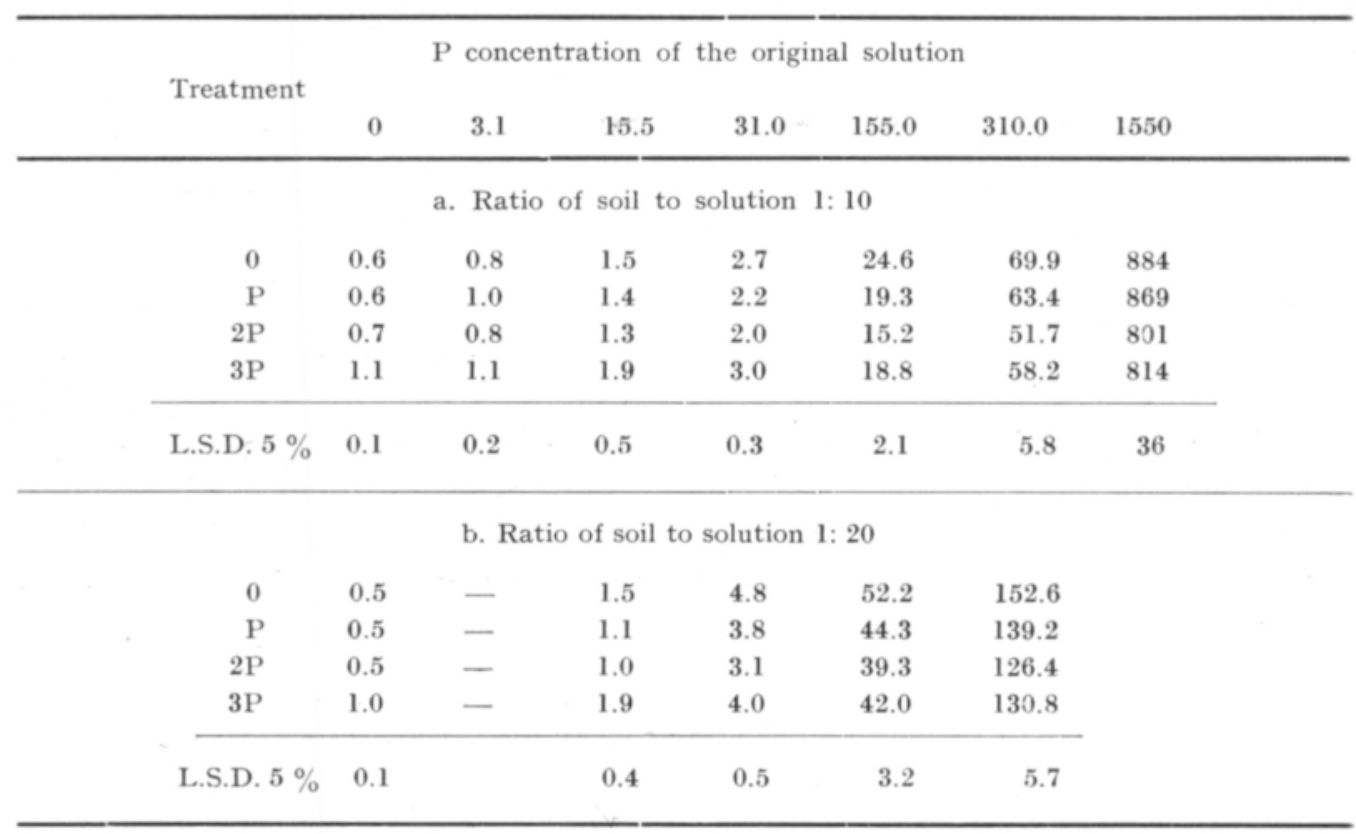

It is of interest to note that the final phosphate concentration is lowest when the samples from treatment $2 \mathrm{P}$ have been used for the removal of phosphate from the solution. This is particularly marked when the phosphorus concentration of the original solution is $31.0 \mathrm{mg} / 1$ or higher. Yet, the $2 \mathrm{P}$ samples were more saturated by exchangeable phosphate than the samples from treatments 0 and P. Even the samples from treatment $3 \mathrm{P}$, despite their fairly high content of exchangeable phos- 
Table 3. Removal of $\mathrm{P}$ from the solution by the peat samples within differen $\mathrm{t}$ periods of contact (Expressed as a percentage of $\mathrm{P}$ in the original solution).

\begin{tabular}{|c|c|c|c|c|}
\hline \multirow[b]{2}{*}{ Treatment } & \multicolumn{3}{|c|}{ Shaking period, hours } & \multirow{2}{*}{$\begin{array}{l}\text { Equilibrium } \\
\text { condition }\end{array}$} \\
\hline & $1 / 2$ & 2 & 4 & \\
\hline 0 & 72.5 & 81.6 & 84.5 & 84.2 \\
\hline $\mathrm{P}$ & 73.0 & 82.9 & 85.9 & 87.5 \\
\hline $2 \mathrm{P}$ & 76.3 & 85.9 & 88.8 & 92.0 \\
\hline $3 \mathrm{P}$ & 73.9 & 83.9 & 87.0 & 87.9 \\
\hline L.S.D. $5 \%$ & 2.5 & 1.8 & 1.6 & 1.4 \\
\hline
\end{tabular}

phate, were able to remove more phosphorus from the solutions of a higher P-concentration than were the samples from the untreated plots which were very poor in exchangeable phosphorus.

The removal of phosphate by the peat samples within different periods of contact between soil and solution is characterized by the figures reported in Table 3 . The ratio of soil to solution was 1 to 10 , and the $\mathrm{P}$ concentration of the original solution was $155.0 \mathrm{mg} / \mathrm{l}$. The $2 \mathrm{P}$-samples have already at the end of a period of half an hour removed more phosphorus from the solution than the 0 -and P-samples.

T able 4. $\mathrm{pH}$, ash content and calcium in the peat samples

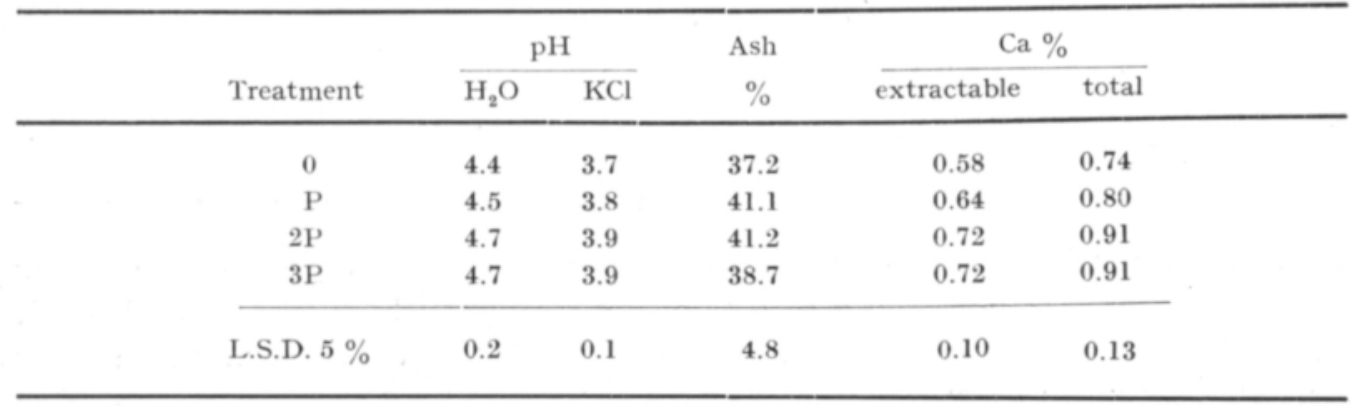

Within a period of 2 hours the removal of phosphate by the $3 \mathrm{P}$-samples was higher than that of the untreated samples. The larger content of exchangeable phosphate in the $3 \mathrm{P}$ samples probably makes them less effective than the $2 \mathrm{P}$ samples as phosphorus retainers.

All these results demonstrate that in this particular peat soil the continuous application of superphosphate at different rates has affected the capacity of the soil to retain phosphate from solution. The higher annual treatments have brought about a higher ability to sorb phosphate, whereas a low annual treatment and no treatment have resulted in a lower phosphate retention capacity.

In order to find factors which may explain the results obtained, the soil samples were analyzed for their $\mathrm{pH}$, their content of ash, calcium, iron, and aluminum. Data recorded in Table 4 show some tendency towards lower acidity with increasing 
phosphate applications. The ash content is fairly high owing to the claying at the beginning of the experimental period. There seems to be no significant difference in the ash content of the variously treated samples, however, which fact excludes the possibility that an unequal distribution of clay between the plots could play a significant part in this respect. Since marked amounts of calcium have been added to the soil in superhosphate, the data for extractable and total calcium in the peat samples tend to be the higher the more intensive the fertilization has been. Nevertheless these figures do not show any difference in the calcium content of the soil from the treatments $2 \mathrm{P}$ and $3 \mathrm{P}$.

The amounts of iron and aluminum extracted by $0.1 \mathrm{~N}$ hydrochloric acid, $2 \%$ citric acid, and Tамм's acid oxalate are reported in Table 5. In spite of the fairly large variations in the replicate plots, an increase in the soluble iron content of the samples with an increase in the annual application of superphosphate is provable. The data for the soluble aluminum show similar tendency, although to a somewhat smaller degree: citric acid, e.g., has dissolved equal amounts of aluminum from all

Table 5. Soluble iron and aluminum in the peat samples, $\mathrm{mg} / \mathrm{kg}$

\begin{tabular}{|c|c|c|c|c|c|c|}
\hline \multirow{2}{*}{ Treatment } & \multicolumn{2}{|c|}{$0.1 \mathrm{~N} \mathrm{HCl}$} & \multicolumn{2}{|c|}{$2 \%$ citric acid } & \multicolumn{2}{|c|}{ Tamm's acid oxalate } \\
\hline & $\mathrm{Fe}$ & Al & $\mathrm{Fe}$ & $\mathrm{Al}$ & $\mathrm{Fe}$ & $\mathrm{Al}$ \\
\hline 0 & 1690 & 3290 & 3370 & 3490 & 9870 & 6660 \\
\hline $\mathbf{P}$ & 1910 & 3610 & 3610 & 3460 & 10230 & 6440 \\
\hline $2 \mathrm{P}$ & 2110 & 3930 & 4000 & 3530 & 11290 & 7280 \\
\hline $3 \mathrm{P}$ & 2190 & 3880 & 4140 & 3540 & 11510 & 7020 \\
\hline L..S.D. $5 \%$ & 330 & 240 & 420 & 360 & 710 & 580 \\
\hline
\end{tabular}

the samples. It is noteworthy that there are no differences between the corresponding data for soluble iron or aluminum in the samples from the treatments $2 \mathrm{P}$ and $3 \mathrm{P}$. The difference between the respective figures for the treatments $\mathrm{P}$ and $2 \mathrm{P}$ is mostly also not significant, but the sesquioxide content of the soil from treatment $2 \mathrm{P}$ is distinctly higher than that of the untreated soil, the citric acid soluble aluminum being the only exception.

\section{Discussion}

The results reported above indicate that in this particular peat soil a continuous application of superphosphate at various rates has brought about apparent differences in the ability of the soil to sorb phosphate. The samples which were more saturated with inorganic phosphate could have been expected to remove less phosphate from the solution than those poorer in exchangeable phosphorus. This, however, was not the case in the present trial. There may be several reasons for the results obtained. Some of them are likely to be found on the basis of the analytical data available. 
Aluminum and iron are the soil constituents which are known to be active in phosphate retention in acid soils. In this trial the content of both aluminum and iron tended to be higher in the soils of the treatments with the larger amounts of superphosphate than, particularly, in the untreated soil. This is the most obvious reason for the corresponding differences in the ability of the samples to sorb phosphate.

In addition to the sesquioxide content, attention must also be paid to the $\mathrm{pH}$ values and the calcium content of the samples. WILD (12) deals with the observation of some earlier authors that soil clay sorbs less phosphate when acid than when saturated with calcium ions, even where precipitation of an insoluble calcium phosphate is precluded by a low $\mathrm{pH}$ value and low concentrations of calcium and phosphate ions. In his experiments the acid clays titrated with calcium hydroxide showed a marked increase in the sorption of phosphate between the $\mathrm{pH}$ range $\mathrm{pH} 4$ to $\mathrm{pH} 5$. The effect was more marked if the treatment was performed at higher temperatures. WILD explains that the exchangeable cations influence phosphate retention by affecting the reaction between phosphate and the aluminum in clay. It is possible that a similar effect also takes place in this clayed peat soil. The results obtained are in accordance with WILn's theory at least in so far that the sorption of phosphate increases with an increase in the content of extractable calcium and $\mathrm{pH}$ values.

Granted that the differences in the contents of soluble aluminum and iron in the first place account for the corresponding differences in the phosphate retention by the samples, there remains the problem of the cause of the unequality in the sesquioxide content. Since there are not available any samples from this peat soil at the outset of the trial it is impossible to conclude whether the present situation arises from an enrichment of iron and aluminum in the ploughing layer of the plots treated with larger amounts of superphosphate, or from the leaching of iron and aluminum from the untreated plots and the plots treated with the lowest amount of superphosphate.

In both cases an important factor may be found in the crops produced during the experimental period. In recent years the yield from the untreated plots has been almost negligible while from the plots of the two highest treatments fairly good yields have been harvested. The lowest application of superphosphate has produced a satisfactory yield. A crop may markedly affect the soil, its temperature and moisture conditions, and its chemical and microbiological character. Thus, it is possible that the larger crops have been able to enrich the ploughing layer with iron and aluminum at the expense of the lower layers, or they may have prevented the leaching of these constituents.

The importance of the crops in this respect is corroborated by the fact that, in spite of the 50 per cent higher annual application of superphosphate to the $3 \mathrm{P}$-plots, their yields, their contents of sesquioxides and their ability to retain phosphate were equal to the corresponding quantities in the $2 \mathrm{P}$-plots. This fact diminishes the significance of the phosphate anion as a precipitation agent of iron and aluminum, although this mechanism may also play its part in the prevention of the possible leaching of sesquioxide. It should be pointed out that according to Mrller (7) the 
precipitated phosphate compounds of iron and aluminium are able to sorb phosphate anions under certain conditions.

Perhaps it is not unwarranted also to pay some attention to the possible direct or indirect effects of calcium and sulphate ions on the solubility and leaching of iron and aluminum.

The observations reported in the present paper may be exceptional and applicable only to this particular peat soil. In any case they are of more interest theoretically than in practice. It must be emphasized that the higher capacity of the fertilized samples to sorb phosphate was apparent only when the phosphate concentration of the solution was fairly high. On the other hand, it is unlikely that the phosphate removed by the peat in the $2 \mathrm{P}$ - and $3 \mathrm{P}$-plots from the soil solution would be fixed so firmly that plants would not be able to absorb it.

\section{$S u m m$ ary}

The phosphate retention by peat samples from a field trial in which superphosphate has been for 34 years applied at annual rates of $0,100,200$, and $300 \mathrm{~kg} / \mathrm{ha}$, respectively, was studied. It was found by various methods that the samples from the plots of the higher treatments were able to sorb more phosphate than were the samples from the untreated plots and the soil with the lowest phosphate application.

The higher content of iron and aluminum in the soils of the higher treatments probably accounts for their higher capacity to retain phosphate. It is possible that in clayed peat soil the higher content of exchangeable calcium and the lower acidity of the samples of the higher treatments are able to increase the effect of aluminum.

The factors which are responsible for the differences in the iron and aluminum contents of the variously treated plots are discussed. It is unlikely that these results would be of importance under practical conditions.

\section{REFERENCES}

(1) Bradley, D. B. \& Sifling, D. H. 1953. Effect of organic anions and sugars on phosphate precipitation by iron and aluminum as influenced by $\mathrm{pH}$. Soil Sci. 76: 175-179.

(2) Hemwall, J. B. 1957. The fixation of phosphorus by soils. In Advances in Agronomy IX: $95-112$.

(3) Hibbard, P. L. 1935. Factors influencing phosphate fixation in soils. Soil Sci. 39: 337-358.

(4) KaIlA, A. 1958. Availability for plants of phosphorus in some virgin peat samples. J. Sci. Agr. Soc. Finland 30: 133-142.

(5) Kunin, R. 1943. Microdetermination of iron by the mercurous nitrate method. Soil Sci. $55: 457$.

(6) Kurtz, T. \& DeTurk, E. E. \& Bray, R. H. 1946. Phosphate adsorption by Illinois soils. Ibid. 61: $111-124$.

(7) Mrller, R. B. 1954. Phosphate relationships of soil and plant XI. Annals Agr. Coll. Sweden 21: $161-175$.

(8) Piper, C. S. 1944. Soil and plant analysis. New York, 368 p.

(9) Swenson, R. M. \& Cole, C. V. \& Sieling, D. H. 1949. Fixation of phosphate by iron and aluminum and replacement by organic and inorganic ions. Soil Sci. 67: $3-22$.

(10) ТАмм, O. 1932. Uber die Oxalatmethode in der chemischen Bodenanalyse. Medd. Statens Skogsförsöksanst. 27: 1-20. 
(11) TERÄSvUORI, A. 1954. Ùber die Anwendung saurer Extraktionslösungen zur Bestimmung des Phosphordüngerbedarfs des Bodens, nebst theoretischen Erörterungen über den Phosphorzustand des Bodens. Publ. Staatl. Landw. Versuchsw. Finnland Nr 141. Helsinki, $64 \mathrm{p}$.

(12) Wild, A. 1953. The effect of exchangeable cations on the retention of phosphate by clay. J. Soil Sci. 4: $72-85$.

S E L O T U S:

\title{
SUPERFOSFAATTILANNOITUKSEN VAIKUTUKSESTA TURVEMAAN FOSFORIN PIDÄTYSKYKYYN
}

\author{
Armi Kaila
}

Yliopiston maanviljelyskemian laitos, Helsinki

Tutkimuksen kohteena oli Leteensuon koeaseman »Koe enenevillä fosforihappomäärillä». Näytteet edustivat koejäseniä, jotka olivat 34 vuoden aikana saaneet vuosittain superfosfaattia $0,100,200$ tai $300 \mathrm{~kg} / \mathrm{ha}$.

Eri menetelmin todettiin, että runsaimmin lannoitettujen koejäsenten maanäytteet pidättivät enemmän fosfaattia kuin niukemmin lannoitetun ja etenkin lannoittamattoman koejäsenen maat. Ilmiö oli sită selvempi, mitä väkevämmästä fosfaattiliuoksesta pidätys tapahtui.

Runsaammin lannoitettujen koejäsenten maissa oli enemmän liukenevaa rautaa ja aluminiumia kuin niukemmin lannoitetun tai lannoittamattoman. Tämän oletettiin ainakin osittain selittävăn saadut tulokset. Lisäksi pidettiin mahdollisena, että edellisten koejäsenten näytteiden suurempi vaihtuvan kalsiumin pitoisuus ja pien€mpi happamuus saattoivat jossain määrin tehostaa aluminiumin ja fosfaatin välisiä reaktioita. 